\section{History of Australian prehistory}

SIR-A recent News item by Tania Ewing (Nature 345, 9; 1990) contains a number of inaccuracies and misconceptions about the department of prehistory in this school, apparently based on allegations made by Dr Johan Kamminga. One is that there has been a 'Cambridge cabal' ensuring that Cambridge graduates dominate the staff appointments and that British graduates get the more senior posts. The facts are that since its establishment in 1961 there have been only seven tenured appointments in the department of prehistory. When the first two tenured appointments were made in the early $1960 \mathrm{~s}$, there were no $\mathrm{PhD}$ graduates in prehistory from any Australian university. Any appointees would have required overseas qualifications. At the time of their appointments, tenured staff held a total of 16 degrees from courses of university studies. Of the 16 degrees, only four were from Cambridge. Five were from Sydney. In 1989, the nine academic staff (tenured and non-tenured) held a total of 21 degrees, three of which were from Cambridge. Five were from Sydney.

Neither is Cambridge dominant as a source of students. Of the 32 students who have completed PhDs in the department, only three took their first degree at Cambridge. Four were from Sydney from a total of 12 from Australian universities.

The assertion that Cambridge dominates is not supported by the facts. One could claim a Sydney network with more justification, but such a claim would be equally untrue. The school, including the department of prehistory, seeks to make the best possible appointment from applicants on the basis of merit, not place of origin.

A major misconception in the article leads to the implication that, following the 1978 review of the school, the department of prehistory is at fault in not shifting its interest towards South-East and East Asia. This was not a general requirement throughout the school. Neither was recruitment of students from these areas a requirement, and indeed has never been a deliberate policy. The school takes students, and awards scholarships, on a competitive basis from all over the world, without any regional preferences. The department of prehistory recruits students interested in working in its field areas, Australia and Melanesia, regardless of the place of origin of the students.

The assertions that electoral committees have been "stacked", that Australian graduates get junior posts while "British

Letters submitted for Correspondence should be typed, double-spaced, on one side of the paper only. graduates get the more senior positions" or that the department of prehistory in this school is a "Cambridge academic colony" are quite simply untrue.

R. GERARD WARD

Research School of Pacific Studies,

Australian National University, GPO Box 4, Canberra, ACT 2601, Australia

SIR - Before your readers conclude that the prehistory department at the Australian National University is a 'Cambridge circus' and especially before there is a rush of Cambridge graduates looking for certain tenured employment in Canberra, I hope you will allow an all-Australian member of the department to correct Tania Ewing's report.

No member of the department has seen Dr Johan Kamminga's allegations so it is difficult to judge whether they are all as inaccurate as the ones he makes public.

In its 21-year history, this research department has had only seven tenured academic staff. Four had Cambridge undergraduate training but two of these obtained Australian PhDs as the basis of their appointment here.

Jack Golson and John Mulvaney were recruited from Auckland and Melbourne respectively to found Australia's first prehistory department in 1969 , so by definition their training was non-Australian. It is not surprisingly that they both received

\section{Ungodly thoughts}

SIR-Am I alone in being surprised at the number of debates, in the pages of Nature, on religion and the existence of god? Most recently this was apparent in the review of Sir John Eccles' new book (Evolution of the Brain: Creation of the Self: Nature 344, $117 ; 1990)$, and the subsequent reply from god (as revealed to Ralph Estling, 344, $582 ; 1990)$. Although, as in this example, references to god in Nature are usually frivolous, this is not always the case (see, for example, 337, 498; 1989), and the ways in which religion affects the world at large are certainly not a laughing matter (as I am sure Mr Salman Rushdie would testify). Yet Nature seems to be according respectability to religious beliefs.

As scientists, should we not be protesting at the way religions permeate society and intrude into our lives, whether or not we want them to? Or, if not protesting, at least making our views known? In a straw poll that I conducted in this medical school, only eight of the 63 people I questioned had any form of religious belief. I suspect that this low incidence of religious beliefs is true of scientists in general, but it would be nice to know for sure.

I would like to suggest that Nature should conduct an opinion poll on the it at Cambridge, then, as now, one of the most distinguished centres of teaching and research in prehistory.

Golson and Mulvaney's ethical and research standards have been major reasons behind the dramatic expansion of prehistory in this region and why the indigenous people of the area have become so interested in it.

It is therefore outrageous for Kamminga to claim that these scholars, two of the world's most respected prehistorians, 'fiddled appointments' from the time they arrived in Canberra.

The next tenured post in the department was not filled until 1972, but your readers can make their own assessments as to whether the subsequent tenured staff - Rhys Jones, Jim Allen, Doug Yen, Matthew Spriggs and myself - had to be 'fiddled' or were appointed because of our publications and research skills.

It is interesting that Kamminga's degrees, like my own, are from the department of anthropology in the University of Sydney. Of the seven tenured prehistorians at our alma mater over the past 29 years, all but two have had at least one Cambridge degree. I am certain though that, like us, they simply make the best appointments on the increasingly rare occasions when there is a vacancy to fill.

ALAN THORNE

Department of Prehistory,

Research School of Pacific Studies,

Australian National University,

Canberra, ACT 2601, Australia

religious beliefs of its readers. If my small sample was typical, such a poll could indicate the strength of the atheist lobby (the silent majority?) in science. What would this achieve? Probably nothing, but who knows? Governments might resolve to bring to a halt the religious indoctrination of children. If children were informed on how many different religions there are, and on the fact that if any one of them happened to be right, all the others would be wrong, they might without much difficulty deduce the liklihood that all religions are wrong. Religious programmes on radio and television could come with a government health warning. People might even begin to realize that what happens to our world depends on us.

Nature would be performing a valuable public service by such a survey. The international readership of the journal would enable us to ascertain whether the prevailing religion of different countries influenced the extent of rejection of religious belief by scientists. Whatever the outcome, it would be good to know how many of us think that man created god (in his own image, of course).

CHRISTOPHER J. LOTE

Physiology Department,

Medical School, University of Birmingham, Birmingham B15 2TJ, UK 